\title{
High-resolution Late-holocene Biomarkers Records in Southern Continental Shelf of the Korean Peninsula: Implications for Climate Variations Over the Last $4 \mathrm{Kyr}$
}

\author{
Sangmin Hyun ( $\sim$ smhyun@kiost.ac.kr) \\ Korea Institute of Ocean Science and Technology \\ Jeongwon Kang \\ KIOST: Korea Institute of Ocean Science and Technology \\ Jin Hyung Cho \\ KIOST: Korea Institute of Ocean Science and Technology \\ Gil Young Kim \\ KIGAM: Korea Institute of Geoscience and Mineral Resources
}

Research article

Keywords: 813 Corg, n-alkanes, paleoclimate, compound-specific isotope, East Asian monsoon

Posted Date: June 29th, 2021

DOI: https://doi.org/10.21203/rs.3.rs-648590/v1

License: (c) (i) This work is licensed under a Creative Commons Attribution 4.0 International License.

Read Full License 


\section{Abstract}

High-resolution records for carbon isotopes of organic matter and $n$-alkane compounds were investigated in two gravity cores (SJP15-2 and SJP15-4) taken from the southern continental shelf of the Korean peninsula to evaluate the influxes of terrestrial biomarkers and their linkage to paleoclimate and marine environmental changes since the last $4 \mathrm{kyr}$. The total organic carbon contents were $<1 \%$, and the carbon isotope ratio of organic matters $\left(\mathrm{d}^{13} \mathrm{C}_{\text {org }}\right)$ ranged from approximately $-21 \%$ o to $-22 \%$ o and, they did not highly fluctuate throughout the two cores. However, the vertical distributions of total terrestrial biomarkers, long-chain $n$-alkanes $\left(n \mathrm{C}_{25-35}\right)$, and individual $n$-alkane compounds exhibited distinctive fluctuations. There are two switching points that discriminate patterns of excursion and distribution at ca. $2.5 \mathrm{ka}$, and $0.5 \mathrm{ka}$. Several $n$-alkane combined indices such as average chain length (ACL), carbon preference index $(\mathrm{CPI})$, and paleovegetation index $(\mathrm{Paq})$ were coincident with these switching points, implying that the supply of terrestrial biomarkers was strongly associated with environmental changes at the source area. In particular, variations of compound-specific $n$-alkanes isotope and the ratios of $n \mathrm{C}_{31} / n \mathrm{C}_{27}$ and $n \mathrm{C}_{31} / n \mathrm{C}_{29}$ follow those of $n$-alkanes indices, implying that this millennium records were associated with wetter climate conditions, and thus paleovegetation and paleoclimate variation. Comparison with previous data of the detrital quartz from the East China Sea and aeolian dust in the Cheju (Jeju) Island, South Korea, and Dongge cave oxygen isotope records indicates strong synchronicity with gradual paleoclimate degradation between $2.5 \mathrm{ka}$ and $0.5 \mathrm{ka}$. Therefore, our high-resolution $n$-alkane data are very useful for reconstructing past climatic variability, suggesting that paleoclimate system of the East Asian region may have influenced the sediment records of study area since the last $4 \mathrm{kyr}$.

\section{Introduction}

Continental shelf and coastal areas are important locations where accumulated terrestrial materials and in situ marine materials can be easily preserved. This means that terrestrial and oceanic records are mixed and reflect past climatological and oceanographic variations. Identification of the sources of terrestrial biomarkers in marine environments and the factors controlling their distributions is important for understanding the global biogeochemical cycle of biomarkers as well as local oceanographic and paleoclimatic environmental changes (Hu et al. 2006; Hyun et al. 2006; Jeng 2006). Such sediments are likely to contain high concentrations of oceanic and terrestrial materials (Stein 1990). However, it is difficult to determine the contributions of certain types of biomarkers to bulk organic matter because most biomarkers are mixed with terrestrial and marine materials. Owing to the complex nature of organic compounds in shallow continental marine environments, various parameters (stable isotope ratios of organic carbon $\left[\delta^{13} \mathrm{C}_{\text {org }}\right]$ and total nitrogen $\left[\delta^{15} \mathrm{~N}_{\mathrm{TN}}\right]$, carbon/nitrogen ratio [C/N ratio], and $n$-alkanes have been widely used to determine the sources of organic matter and related environmental interpretation (Minoura et al. 1997; Naidu et al. 2000; Cloern et al. 2002; Usui et al. 2006; McKirdy et al. 2010).

As one of the most significant terrestrial organic materials, $n$-alkanes have been widely used to determine organic matter sources and climatic variation in various locations (Jeng 2006; Eglinton and Eglinton 
2008; Yamamoto et al. 2010; Chu et al. 2014). In particular, because high-molecular-weight long-chain $n$ alkanes such as $n \mathrm{C}_{27}, n \mathrm{C}_{29}$, and $n \mathrm{C}_{31}$ are major constituents of vascular land plants (Sikes et al. 2009; Yamamoto et al. 2010; Bush and Mclnerney 2013), sedimentary $n$-alkanes are potentially important for determining the sources of organic matter and related environmental changes, including paleoclimate variation. The abundance of these waxy hydrocarbons reflects the amount of organic matter transported to lake beds, alluvial deposits, marine sediment, and rivers from the surrounding land, making it possible to determine their contribution to the terrestrial organic matter flux. Therefore, these proxies provide insight into organic matter sources, past environmental changes, including vegetation changes (Zhang et al. 2006; Yamamoto et al. 2010), and local and global paleoclimate environmental variations (Horikawa et al. 2010; Seki et al. 2006; Street et al. 2013; Li et al. 2013; 2015).

As a component of global climate changes, the East Asian monsoon system and its variation have been investigated through the various proxy data (Nagashima et al. 2013; Wang et al. 2014; Tada et al. 2016; Wang et al. 2020). In East Asia, variation of the East Asian Summer Monsoon (EASM) and East Asian Winter Monsoon (EAWM) has been a focused because many studies have shown that the monsoon signal and its intensity differs from among scientific datasets (Li et al. 2013; Wang et al. 2014; 2020). Some signals show coincident variations, while others are inconsistent in terms of EASM and EAWM intensity (An 2000; Wang et al. 2020). Regarding the Holocene climatic variation, it is strongly coupled with enhanced and/or reduced precipitation due to the latitudinal shift of EASM intensity. This earlier study indicates that the oscillation of EASM front results in deepest northwestward penetration make enhanced EASM during the period 3.5-2.0 kyr, and southeastward retreat (weak EASM) occurred during the period 2.0-0 kyr (Wang et al. 2020). Also this precipitation changes supported by the other proxies of eolian dust that transported in accordance to the westerly jet (WJ) path over the East Asia region (Nagashima et al. 2013).

Our study area is within the East Asian monsoon belt; therefore, the sediments of this study may reflect past climatic variations in the scope of the East Asian region. As long-chain $n$-alkanes from this studied core are likely to reveal changes in terrestrial influx by river and atmosphere under the influence of East Asian monsoon climate regime, we investigate $n$-alkanes variability recovered from southern inner continental shelf. The purpose of the present study is the reconstruction of past $n$-alkane influxes and their relationships with in situ paleoceanographic and paleoclimate variabilities since the mid-Holocene.

\section{Materials And Methods}

\subsection{Geological and oceanographic setting}

The southern coastal area of the Korean peninsula is characterized by a complex geomorphology and shallow water depth. It is expected that large influxes of terrestrial material have been supplied from large and small river systems such as the Seomjin River in study area (Fig. 1). The Seomjin River, located on the extreme southern coast of Korea, is characterized by a large outward flow of fresh water throughout the year, with an annual discharge of approximately $7.2 \times 10^{8} \mathrm{~m}^{3}$ of fresh water to Gwangyang Bay 
(Korea Ministry of Construction, KMC 1980). The average suspended sediment accumulation rate in the river mouth is $\sim 17.8 \mathrm{mg} / \mathrm{L}$ in the bottom layer and $4.8 \mathrm{mg} / \mathrm{L}$ in the surface layer, which results in an estimated deposited mass of $0.8 \times 10^{6}$ tons per year (Kim and Kang 1991). Considering the sea level changes of southern coastal area of Korean peninsula, it has been considered that the sea level was reached at present level around the $6 \sim 7$ ka before (Park et al. 2000; Yoo et al. 2014), therefore Yeosu Bay, a major catchment area of the Seomjin River, has been subject to sediment accumulation since the early Holocene.

Besides direct supply from the neighboring inland area, there are other sediment transportations resulting from the regime of the East Asian monsoon belt. Materials could be transported through air, and suspended materials could be transported by the Korean Coastal Current (Fig. 1). Therefore, the high sedimentation rate of the studied cores makes it possible to reconstruct high-resolution records reflecting past monsoon signals as well as in situ local paleoceanographic and paleoclimate variations.

As the two cores used in this study were taken from nearby locations, the lithological characters were very similar and reserve paleoclimatic and paleoceanographic information. To acquire information and improve our understanding of the Late-Holocene paleoclimate variation, we gathered Holocene paleoclimatic data from cores acquired from the Cheju Island, South Korea (Lim and Matsumoto 2008), and a coastal area of the Yangtze River, China (Wang et al. 2020).

\subsection{Sampling}

A total two gravity piston core samples were collected from the outer part of Seomjin River, inner shelf of the Southern Sea of Korean Peninsula using a gravity piston core (Fig. 1). After sedimentological study of the two piston core, total 57 samples were collected for the analysis of total organic carbon (TOC), and carbon and nitrogen isotopes, $n$-alkanes. TOC, carbon $\left(\delta^{13} \mathrm{C}_{\text {org }}\right)$ isotopes in organic matter, and $n$-alkanes were analyzed to determine the time-dependent variation of the source of the organic matter and its distribution. Also sampling for carbon ${ }^{14} \mathrm{C}$ ages sediment samples were collected. Based on the sedimentary feature, a total 17 radio carbon ${ }^{14} \mathrm{C}$ ages samples were determined using sedimentary organic matters and carbonate shell fragments at Beta-isotope (Table 1).

\subsection{Carbon isotope of organic matter and $n$-alkane}

Isotopic composition of sedimentary organic matter was determined after treatment with $1 \mathrm{M} \mathrm{HCl}$ overnight to remove carbonate materials and then subsequently rinsed with deionized water three times before freeze drying. The percentage of total carbon and nitrogen as well as their isotopic composition $\left(\delta^{13} \mathrm{C}_{\text {org }}\right)$ from the carbonate free samples were determined using EA-CF-IRMS. The isotope ratios of standards in the laboratory was measured three times on three separate occasions and quoted an instrumental measurement precision of $\pm 0.01 \%$ o for carbon and $\pm 0.03 \%$ o for nitrogen. To ensure quality control, each analysis run included international standards. All analytical process was conducted at the Iso-analytic in UK. 
For the analysis of $n$-alkanes, lipids were extracted from dried sediment (about $10 \mathrm{~g}$ ) over three extraction cycles using a DIONEX Accelerated Solvent Extractor (ASE 200) at $100^{\circ} \mathrm{C}$ and 1500 psi with dichloromethane (DCM)/methanol (MeOH) (95:5). The extracted lipid was saponified with $1 \mathrm{~N}$ $\mathrm{KOH} / \mathrm{MeOH}$, and neutral lipid was separated by hexane extraction. The extracted neutral lipid was further separated into four fractions using silica gel column chromatography: F1 (hydrocarbon), F2 (aromatic hydrocarbon), F3 (ketones), and F4 (polar compounds). The F1 fractions were eluted with hexane (100\%), hexane/DCM (2:1, v/v), DCM (100\%), and DCM/MeOH (95:5, v/v), to analysis of $n$-alkanes.

Gas chromatography (GC) was used for the analysis of $n$-alkanes in the F1 fraction using a Hewlett Packard 6890 series GC unit, with a split/splitless injector operated in a pulsed splitless mode, and electronic pressure control systems and a flame ionization detector (FID). A CP Sil5CB column $(60 \mathrm{~m} \times$ $0.32 \mathrm{~mm}$ i.d.) was used with the oven temperature programmed at $50-120^{\circ} \mathrm{C}$ at $30^{\circ} \mathrm{C} / \mathrm{min}, 120-320^{\circ} \mathrm{C}$ at $7^{\circ} \mathrm{C} / \mathrm{min}$, and then held at $320^{\circ} \mathrm{C}$ for $50 \mathrm{~min}$. Prior to the quantification of lipids, a known aliquot of an internal standard, $5 \mathrm{a}$-Cholestane, was added to the hydrocarbon fraction. Individual aliphatic ( $n$-alkane) compounds were identified and quantified using the retention times of $n$-alkanes and the mass spectrum of selected ions from calibration standards at concentrations ranging from 10 to $200 \mu \mathrm{g} / \mathrm{ml}$.

Analytical quality control was carried out to make sure that the results are consistent, comparable, within specified limits of precision and accurate. $n$-alkane standard mixtures were injected to the GC/MS three times to have an absolute retention time of each individual compounds. Individual compounds of $n$ alkanes in samples were identified and quantified based on the retention time and mass spectrum of selected ions with the calibration standards. Samples were spiked with a surrogate standard ( $\mathrm{n}$ Triacontane d62). After final concentration, the extracts were spiked with internal standard ( $5 \mathrm{a}-$ Cholestane). A $70-90 \%$ surrogate recovery was seen from all samples.

After $n$-alkane analysis, the fractions were used for the individual $n$-alkane carbon isotope $\left(\delta^{13} \mathrm{C}_{\mathrm{ALK}}\right)$ analysis using the GC/IRMS at Woods Hole Oceanographic Institute (WHOI), USA. A total of $1 \mu$ l of the $n$ alkane concentration was injected into a fused silica capillary column (30 $\mathrm{m} * 0.32 \mathrm{~mm}$ i.d.), with helium used as carrier gas. The GC oven temperature was programmed with a stepwise increase from 50 to $310^{\circ} \mathrm{C}$ at rates of $30^{\circ} \mathrm{C}, 6^{\circ} \mathrm{C}$, and $9^{\circ} \mathrm{C} / \mathrm{min}$. All $\delta^{13} \mathrm{C}_{\mathrm{ALK}}$ values were checked for precision and accuracy to interpret small differences in $\delta^{13} \mathrm{C}_{\mathrm{ALK}}$ values. The standard material (Methyl heneicosanoate, $\mathrm{C}_{22} \mathrm{H}_{44} \mathrm{O}_{2}$ ) was used and the precisions of its $\delta^{13} \mathrm{C}_{\mathrm{ALK}}$ values obtained by GC/IRMS analyses were reported as the standard deviations $(\sigma)$ of populations of at least three analyses. The standard deviation of GC/IRMS data for $n$-alkanes was usually less than $0.3 \%$.

\section{Results And Discussion}

\subsection{Sediment characteristics and age model}

In order to track any past records from the core sediment, it is fundamental to understand the sediment characteristics. This means sedimentological examination is the first step to identifying past 
environmental changes. Based on the detailed examination of the sedimentary structure of the two core, the core sediments reveal typical hemipelagic sediment characteristics, having massive structures and being composed of homogenous clay materials. The examination begins with age determination on the sediment column, which may clarify high-resolution time-dependent environmental records in terms of terrestrial influx from nearby land areas as well as in situ oceanographic variations. The sedimentary features and sedimentation rates preserved in these two cores suggesting that the sedimentary environment did not change significantly throughout deposition since the last $4 \mathrm{ka}$. This may imply that the sediments preserve continuous in situ oceanographic and climatic records. In particular, coring site belongs to East Asian monsoon belt, it can provide monsoon climatic signal as well as local coastal environmental changes.

According to the carbon-14 $\left({ }^{14} \mathrm{C}\right)$ age results, which were obtained by radiocarbon age dating at Beta Analytic Inc. (Miami, FL, USA), the age model for the SJP15-2 core was determined using ${ }^{14} \mathrm{C}$ bulk organic matter (BOM) and carbonate shell fragment (CSF) as reference data produce two regression lines. The slopes of the BOM- and CSF-based regression lines were nearly parallel, showing larger age differences toward surface sediments (Fig. 2A). To avoid the contamination of BOM-based ${ }^{14} \mathrm{C}$ ages by the ${ }^{14} \mathrm{C}$ reservoir effect caused by older terrestrial carbon (Ikehara, 2000; Zhou et al. 2018), these age differences were transformed into real ages for detailed comparisons. Because CFS-based ${ }^{14} \mathrm{C}$ ages are also susceptible to contamination by the reservoir effect, we assumed a global average reservoir effect of 2300 years, and a surface sediment age of 0 years (i.e., the present year), despite an intercept of $0.11 \mathrm{ka}$ for the SJP15-2 core (Fig. 2A).

Similarly, regression lines for the SJP15-4 core age model were constructed using BOM data, followed by CSF data. The SJP15-4 core was estimated to be older according to the BOM-based regression line than by the CSF-based line, with an age difference of about 1863 years at a depth of $136 \mathrm{~cm}$. Therefore, we drew hypothetical lines within the age gap between the BOM- and CSF-based regression lines at a depth of $136 \mathrm{~cm}$, using the SJP15-2 regression lines as a reference. The slopes of the new regression lines for the SJP15-4 core were similar to those of SJP15-2, with surface sediment age differences between the BOM- and CSF-based lines of about $1.69 \mathrm{ka}$ and $2.04 \mathrm{ka}$ for the SJP15-2 and SJP15-4 cores, respectively. This result suggests higher contamination by older carbon in the SJP15-4 core (Fig. 2B). However, the intercept ages of surface sediments in both cores ( 0.11 and 0.35 ka for the SJP15-2 and SJP15-4 cores, respectively) were offset to 0 years for convenient age model establishment. Thus, the age data have an uncertainty of 100-300 years, which is similar to the global average reservoir effect of 2-300 years (Alves et al. 2018).

Based on this ${ }^{14} \mathrm{C}$ age determination, the average sedimentation rates of the two cores were quite high, it was $120 \mathrm{~cm} / \mathrm{kyr}$ for core SJP15-2 and $159 \mathrm{~cm} / \mathrm{kyr}$ for core SJP15-4, respectively, exhibiting typical features of coastal and hemipelagic sediment. This high sedimentation rate makes it possible to track the influx of terrestrial biomarker since the mid-Holocene. The results of ${ }^{14} \mathrm{C}$ ages for the two cores are summarized in Table 1. 


\subsection{Variations of total organic carbon (TOC, \%), $\delta^{13} \mathrm{C}_{\text {org }}$, and $\delta^{15} \mathrm{~N}_{\mathrm{TN}}$}

The sediment of SJP15-2 (inner shelf) and SJP15-4 (outer shelf) showed a narrow range of TOC variation, remaining almost constant throughout except for several upper samples, which showed a slight decrease in SJP15-2, and increase in SJP15-4. Overall, TOC contents in the sediments of the two cores show narrow range of fluctuation, ranging from $0.6-0.9 \%$ (average $=0.71 \%, n=53$ ) (Fig. 3).

$\mathrm{A} \mathrm{C} / \mathrm{N}$ ratio has been used to determine the source of organic matter even though it could not provide critical criteria where they are come from. For example, when the $\mathrm{C} / \mathrm{N}$ ratio of organic matter $>12$ indicates a terrigenous source, whereas a ratio $<12$ indicates a marine source (Stein 1990). Given that the $\mathrm{C} / \mathrm{N}$ ratios of organic matter in both cores were $<10$, larger portion of organic matters were derived from in situ bio-productivity. Meanwhile, the surface distribution of TOC from the nearby areas reflects a mixture of marine and terrestrial sources (Badejo et al. 2017). Also large portion of terrestrial organic matter were contained in the sediment of the southern part of the coastal area (Hyun et al. 2011). Therefore, the TOC contents of the two cores sediment may come from a mixture of terrestrial and marine sources.

Like TOC contents and $\mathrm{C} / \mathrm{N}$ ratios, $\delta^{13} \mathrm{C}_{\text {org }}$ and $\delta^{15} \mathrm{~N}_{\mathrm{TN}}$ values have also been used to determine the sources of organic carbon. In present study, $\delta^{13} \mathrm{C}_{\text {org }}$ values ranged from $-22 \%$ o to $-21 \%$ o (average $=-$ $21.4 \%$ o, $n=41$ ) in both core sediments, showing typical marine productivity-related organic carbon sources when considering its endmember in neighboring sites (Hyun et al. 2011). The $\delta^{13} \mathrm{C}_{\text {org }}$ value of marine particulate organic matter ranges from - 22\%o to - 18\%o (Middelburge and Nieuwenhuize, 1998), whereas lower values between $-33 \%$ and $-22 \%$ are considered to reflect terrestrial origins (Pancost and Boot 2004). Because lighter ratios indicate marine sources (the marine endmember value is approximately $-20 \%$ ond the terrestrial endmember value is $-27 \%$ ), the values in the two cores sediment indicating that most of the organic carbon was produced by in situ marine bioproductivity.

Surface sediments from the catchment areas showed that relatively high amounts of terrestrial organic carbons were supplied (Hyun et al. 2011; Badejo et al. 2017). The heavier values of $\delta^{13} \mathrm{C}_{\text {org }}$ upward in SJP15-4 may be attributable to a higher portion of marine sources or to diminishing terrestrial organic carbon. However, in the inner shelf, core SJP15-2 showed a relatively narrow range of $\delta^{13} \mathrm{C}_{\text {org }}$, implying a higher portion of terrestrial organic carbon compared to SJP15-4. Similar $\delta^{13} \mathrm{C}_{\text {org }}$ values were recognized in nearby surface sediments, indicating mixtures of terrestrial and marine organic matter, while the $\delta^{13} C_{\text {org }}$ values of the Seomjin River predominantly indicate a terrestrial endmember (Badejo et al. 2017). The results indicate that the organic matter deposited in the study area was delivered not directly from the Seomjin River but was mixed with biogenic sources and other origins. A notable depletion of $\delta^{13} \mathrm{C}_{\text {org }}$ in surface sediments was observed around the catchment areas of Gwangyang Bay and Yeosu Bay, which had relatively low $\mathrm{C} / \mathrm{N}$ ratios of $<10$ (Hyun et al. 2011); data from the neighboring areas indicates 
that organic carbon has been deposited from various sources, and the mixture of terrestrial and oceanic sources differed from their site.

The uppermost lighter ratios of $\delta^{13} \mathrm{C}_{\text {org }}$ and $\delta^{15} \mathrm{~N}_{\mathrm{TN}}$ in SJP15-2 are associated with lower organic carbon contents. One simple explanation for this is the presence of inorganic nitrogen, presumably as ammonium absorbed onto clay, in the surface sediments, which can interfere with the identification of organic matter sources when applying the $\mathrm{C} / \mathrm{N}$ ratio (Kang et al. 2007; Hu et al. 2009). This assumption is supported by the $\delta^{15} \mathrm{~N}_{\mathrm{TN}}$ values (Fig. 3), which had a similar distribution to that of the $\mathrm{C} / \mathrm{N}$ ratio. The observed variation in $\delta{ }^{15} \mathrm{~N}_{\mathrm{TN}}$ could be the result of a change in the nitrate supply, which could be in the form of nitrate fertilizer around the catchment area and a marine nitrate source in the inner shelf study area. Because the onset of $\delta^{13} \mathrm{C}_{\text {org }}$ increase has occurred at $2.5 \mathrm{ka}$ and $3.5 \mathrm{ka}$ in SJP15-4 and SJP15-2, respectively, it may reflect a gradational increase of bioproductivity. The TOC and $\delta^{13} \mathrm{C}_{\text {org }}$ excursions coincide, the lower $\mathrm{C} / \mathrm{N}$ ratio of $\sim 8$ supports in situ bioproductivity. Even though gradational increases of $\delta^{13} \mathrm{C}_{\text {org }}$ in both core were observed and interpreted as bioproductivity variation, terrestrial biomarker such as $n$-alkanes also could be supplied. Because $\delta^{13} \mathrm{C}_{\text {org }}$ values are not an end-member of biogenic source, therefore, it was mixed with mainly marine and minor terrestrial organic matter.

\subsection{Concentration and distribution of terrestrial $n$-alkanes}

In addition to $\delta^{13} \mathrm{C}_{\text {org }}$ and $\delta^{15} \mathrm{~N}_{\mathrm{TN}}$, terrestrial $n$-alkanes provide detailed information on source-related organic compound characteristics because each $n$-alkane compound can reflect a specific source. For example, among the long-chain $n$-alkanes, $n \mathrm{C}_{29}$ and $n \mathrm{C}_{31}$ are predominately derived from terrestrial plant waxes, whereas the mid-chain $n$-alkanes $n \mathrm{C}_{20}$ and $n \mathrm{C}_{23}$ are indicative of different floating macrophyte groups (Visco et al. 1993; Fricken et al. 1998). This means that both middle $\left(n \mathrm{C}_{21}, n \mathrm{C}_{23}\right)$ and longer $\left(n \mathrm{C}_{29}\right.$, $n \mathrm{C}_{31}$ ) chain lengths can be traced to aquatic and terrestrial sources with excellent confidence. In a broad sense, the overall distribution of $n$-alkane concentrations is consequence of vegetation changes, thus climatic changes in source area.

An overall distribution of $n$-alkanes is characterized by predominant odd-number long-chain alkanes concentration $\left(n \mathrm{C}_{27-33}\right)$. The total $n$-alkane concentration $\left(n \mathrm{C}_{25}-n \mathrm{C}_{35}\right)$ showed large fluctuations, ranging from 1272 to $274 \mu \mathrm{g} / \mathrm{g}$ (average $=728 \mu \mathrm{g} / \mathrm{g}, n=27$ ) in core SJP15-2, and from 3056 to $339 \mu \mathrm{g} / \mathrm{g}$ (average $=773 \mu \mathrm{g} / \mathrm{g}, n=30$ ) in core SJP15-4, respectively (Fig. 4). The vertical distribution of $n$-alkanes between the two cores was harmonious, but it was slightly different in terms of the concentration of midchain $n$-alkanes $\left(n \mathrm{C}_{22}, n \mathrm{C}_{24}, n \mathrm{C}_{25}\right.$ and $\left.n \mathrm{C}_{26}\right)$. However, in detail, the vertical distribution was characterized by a distinctive increase in the total concentration from $2.8 \mathrm{ka}$ to $1.3 \mathrm{ka}$ in core SJP15-2, and from $3.0 \mathrm{ka}$ to $0.5 \mathrm{ka}$ with abrupt increase at the layers of $0.2 \mathrm{ka}$ in core SJP15-4.

The timing of onset of increase in several individual $n$-alkanes are different from each other. Individual $n$ alkane such as $n \mathrm{C}_{29}, n \mathrm{C}_{31}, n \mathrm{C}_{33}, n \mathrm{C}_{35}$ in two core start to increase at $2.5 \mathrm{ka}$, but these four $n$-alkanes group differ from other group $\left(n \mathrm{C}_{28}, n \mathrm{C}_{30}, n \mathrm{C}_{32}\right)$ that shows distinctive increase from 2.0 ka. Given that 
long-chain $n$-alkanes such as $n \mathrm{C}_{29}$ and $n \mathrm{C}_{29}+n \mathrm{C}_{31}$ are considered proxies for forest and/or grassland vegetation, the excursions of these $n$-alkanes can provide information on paleoclimate variation because they are derived from terrestrial higher plant waxes (Eglinton and Hamliton 1967). Therefore, the major changes in above mentioned long-chain odd-carbon-numbered $n$-alkanes reflect shifts in terrestrial vegetation at the source area, as well as shifts in the photosynthetic pathway. This variation directly can be interpreted as vegetation community changes, thus climate changes.

The abrupt increasing of even numbered $n$-alkanes, $n \mathrm{C}_{22}$ and $n \mathrm{C}_{24}$ occurred around $2.5 \mathrm{ka}$ in the cores SJP15-4, is very meaningful (Fig. 4). This may imply some submerged vegetation has been flourished in this interval. Also, the strong increase of $n \mathrm{C}_{24}$ and $n \mathrm{C}_{26}$ appeared at $1.2 \mathrm{ka}$ in core SJP15-2 can be explained as flourish of floating macrophyte. Similarly, the increase of mid-chain $n$-alkanes $\left(n \mathrm{C}_{21}, n \mathrm{C}_{23}\right)$ has been observed during mid-late Holocene at the Swamp Lake of USA, and this mid-chain increase was explained by an increase in the abundance of aquatic plants and availability of shallow water habitat in rising lake level (Street et al. 2013). Therefore, increase of mid-chain $n$-alkanes occurred around $2.5 \mathrm{ka}$ in core SJP15-4 might be associated with temporal environmental changes due to the flourishing of aquatic plants under the shallow water environment.

The comparison of each numbered $n$-alkane concentration of the two core can provide more detailed time-dependent variations (Fig. 5). Long-chain $n$-alkane such as $n C_{29}, n C_{31}$ are predominantly present throughout the two core. However, mid-chain $n$-alkane such as $n C_{24 \sim 26}$ are differ from each other. The concentration of mid-chain $n$-alkane in SJP15-4 is relatively higher than that of SJP15-2 at around of 0.5 $\mathrm{ka}$, whereas it is less at $1.2 \mathrm{ka}$ than that of SJP15-2 at $1.12 \mathrm{ka}$ (Fig. 5). Therefore, as shown in Fig. 4 and Fig. 5 , each $n$-alkane concentration has been differentiated from time to time in each core site, implying time-dependent mid-chain $n$-alkane fluctuation in accordance to climatic and vegetation changes.

Badejo et al. (2017) examined $n$-alkane concentrations from the surface sediment in nearby area, and suggested large inputs of materials from the mouth of the Seomjin River to the inner shelf area, with a slight variation that could be due to an indirect supply. According to that results, the influx of terrestrial material was higher near the Seomjin River mouth, decreasing further offshore. Therefore, various $n-$ alkane compounds have been expected to being supplied from a nearby source by Seomjin River and possible faraway mainland sources.

As combined proxies, spatiotemporal distribution of average chain length (ACL) and carbon preference index $(\mathrm{CPI})$ of the $n$-alkanes also have been used to determine the characteristics of organic carbon since they can provide valuable information on $n$-alkane sources (Sikes et al. 2009; Jia et al. 2015; Li et al. 2015). In particular, the distribution of ACL has been linked to the geographical distribution of fluvial, aeolian inputs and source regions (Poynter and Eglinton 1990). Therefore, it is possible to delineate $n$ alkane sources by identifying environmental differences, even though the usefulness of this approach is limited to a source-specific $n$-alkane distribution (Jeng 2006). 
In our study, there was a narrow and distinctive variation in the ACL with a similar trend between $3.0 \mathrm{ka}$ and $1.0 \mathrm{ka}$ in two core sediments. A clear difference between the two cores seem to appear around ca. 0.8 ka (Fig. 6). Overall, values of ACL in our core start to increase at $3.5 \mathrm{ka}$, and it describe a parabola until 1.0 ka with a peak around at $2.0 \mathrm{ka}$. Given that ACL refer to average number of carbon atoms per molecule based on the abundance of the odd-carbon-numbered higher plant $n$-alkane (Poynter and Eglinton 1990), this gradual increase and decrease interval implies the variabilities of alkane distribution, i.e., it might be related to gradational drier and wetter climatic condition. One possible reason for the variation in the distribution is the ACL variation of $n$-alkanes in different plant species. Based on this decreased ACL interval from $2.0 \mathrm{ka}$ to $1.0 \mathrm{ka}$, we infer that our study area also experienced a susceptible East Asian monsoon climatic changes within this millennium scale.

$\mathrm{CPI}$ values of the waxes also provide additional information on $n$-alkane source because it originates from terrestrial plant community. Usually it shows wide range of variation; terrestrial higher plants usually have values of $5 \sim 10$ (Hedges and Prahl 1993), lower values $<1$ is thought to oil contamination in modern sediments (Jeng 2006; Seki et al. 2006). In the present study, the average CPI of 3.06 (range = 1.74-4.93) in core SJP15-2, and 3.2 (range = 1.77-4.38) in core SJP15-4, respectively. The highest value (4.93) occurred at $0.5 \mathrm{ka}$ at SJP15-2 close to Seomjin River/inner shelf area, possibly associated with an influx of $n$-alkanes from a terrestrial leaf wax source. However, CPI values in both core are not show any particular trends, so it is difficult to evaluate whether core sediments were contaminated or not, even though CPI values < 3 indicate oiled sediments (Farrington and Tripp, 1977).

Like $\mathrm{ACL}$ and $\mathrm{CPI}$, the $\mathrm{P}_{a q}$ is indicative of paleovegetation changes (Yamamoto et al., 2010). Sike et al. (2009) used this paleo $n$-alkane index to detect the pattern of paleovegetation as follows: $\mathrm{P}_{a q}=\left(\mathrm{C}_{23}+\right.$ $\left.\mathrm{C}_{25}\right) /\left(\mathrm{C}_{23}+\mathrm{C}_{25}+\mathrm{C}_{29}+\mathrm{C}_{31}\right)$. This formula indicates the relative abundance of $\mathrm{C}_{3}$ plants with respect to $\mathrm{C}_{4}$ plants. Increasing $\mathrm{P}_{a q}$ values indicate an increasing ratio of $\mathrm{C}_{23}$ and $\mathrm{C}_{25}$. A $\mathrm{P}_{a q}$ value $<0.1$ corresponds to terrestrial plants; $0.1-0.4$ corresponds to emergent macrophytes; and $0.4-1$ corresponds to submerged macrophytes (Ficken et al. 2000). In our study, the values of $\mathrm{P}_{a q}$ does not exceed 0.4 , but it includes increased interval from $2.0 \mathrm{ka}$ to $0.8 \mathrm{ka}$ in two cores with a peak at $0.8 \mathrm{ka}$ (Fig. 6). Thus, the increasing tendency from $2.0 \mathrm{ka}$ to $0.8 \mathrm{ka}$ indicates an expansion of $\mathrm{C}_{3}$ plants. This means that the $\mathrm{P}_{a q}$ is strongly associated with the ACL and CPI, both of which indicate climatic and paleo-vegetation changes.

Similarly, $n \mathrm{C}_{31} / n \mathrm{C}_{23}, n \mathrm{C}_{31} / n \mathrm{C}_{25}, n \mathrm{C}_{31} / n \mathrm{C}_{27}$ and $n \mathrm{C}_{31} / n \mathrm{C}_{29}$ ratios also widely used as an indicator of past paleovegetation and paleoclimate variation (Hanisch et al. 2003; Xie et al. 2003; Zech 2006; Horikawa et al. 2010). As a whole, these indices show very similar excursion with ACL and opposite trend with respect to $\mathrm{P}_{a q}$ between $3.5 \mathrm{ka}$ and $1.0 \mathrm{ka}$ (Fig. 6). This interval from $3.5 \mathrm{ka}$ to $1.0 \mathrm{ka}$ corresponds well with the increase of the concentration of long-chain $n$-alkanes, heavier trending $\delta^{13} \mathrm{C}(\%)$. All of these proxies show a clear change between $3.5 \mathrm{ka}$ and $1.0 \mathrm{ka}$, supporting vegetation and climate changes. This climate condition supported by expansion of $\mathrm{C}_{4}$ plant between $3.5 \mathrm{ka}$ and $2.5 \mathrm{ka}$, and again relative expansion of C3 from $2.5 \mathrm{ka}$ to $1.0 \mathrm{ka}$, as increase of Paq as shown in Fig. 6. All of multiple proxies of these ACL, CPI and $\mathrm{Paq}$ are very useful to understand paleovegetation and paleoclimate variations in study area. 


\subsection{Individual carbon isotopes of $n$-alkanes $\left(\delta^{13} \mathrm{C}_{\mathrm{ALK}}\right)$ and sources}

The compound-specific isotopic ratio in $n$-alkane $\left(\delta^{13} \mathrm{C}_{\mathrm{ALK}}\right)$ has higher potential for complementing $n$ alkane distributions and providing more reliable $n$-alkane provenances because $n$-alkane isotopes show no fractionation during photo-oxidation and microbial degradation (Collister et al. 1994; Ahad et al. 2011). This means that different sources result in different characteristics for $\delta^{13} \mathrm{C}_{\mathrm{ALK}}$ values. Previous research showed that $\delta^{13} \mathrm{C}_{\mathrm{ALK}}$ values for $\mathrm{C}_{4}$-derived $n$-alkanes were all within the range of $-18.5 \%$ o to $24.5 \%$, and those for $\mathrm{C}_{3}$-derived $n$-alkanes were more depleted, ranging from approximately $-31.4 \%$ o to - 38.6\%o (Collister et al. 1994). For this reason, $\delta^{13} C_{A L K}$ has been widely used for compound source discrimination in various environments (e.g., Jeng 2006; Ahad et al. 2011).

In this study, the entire range of odd-numbered $n$-alkane carbon isotopes $\left(\delta^{13} \mathrm{C}_{\mathrm{ALK}}\right)$ showed overall comparable excursions (Fig. 7). The distribution and the entire range of odd-numbered $\delta^{13} \mathrm{C}_{\mathrm{ALK}}$ does not show homogenous excursion, but it has a switching points at around $1.0 \mathrm{ka}$. Judging from the criteria reported previous result, our $\delta^{13} \mathrm{C}_{\mathrm{ALK}}$ ratio ranged from about $-21 \%$ o to $-31 \%$ is regarded as intermediate ratio of $\mathrm{C}_{3}$ and $\mathrm{C}_{4}$ plants, thus as mixture of $\mathrm{C}_{3}$ and $\mathrm{C}_{4}$-drived consequence. In particular, the $\delta^{13} \mathrm{C}_{\mathrm{ALK}}$ excursions are very complicated and characterized by an abrupt negative shift of $\delta^{13} n \mathrm{C}_{21}, \delta^{13} n \mathrm{C}_{23}$, $\delta^{13} n C_{25}, \delta^{13} n C_{33}$ in SJP15-4 at $1.0 \mathrm{ka}$. Whereas, a positive shift of $\delta^{13} n C_{23}, \delta^{13} n C_{25}, \delta^{13} n C_{33}, \delta^{13} n C_{35}$ in SJP15-2 at $1.0 \mathrm{ka}$ can be recognized. The excursions of these individual $\delta^{13} \mathrm{C}_{\mathrm{ALK}}$ values were decoupled in several compounds such as $n \mathrm{C}_{23}$ and $n \mathrm{C}_{33}$. Among floating macrophytes groups, such as $n \mathrm{C}_{21}, n \mathrm{C}_{23}$, and $n \mathrm{C}_{25}$, seems to differ from each other, and also the excursion of this group can be distinguished from emerged land macrophytes, such as $n \mathrm{C}_{29}, n \mathrm{C}_{31}$, and $n \mathrm{C}_{33}$ (Fig. 7). As mentioned previously, because of the different sources of $n$-alkane isotopes have different values for $\delta^{13} \mathrm{C}_{\mathrm{ALK}}$, the wide variation of $\delta^{13} \mathrm{C}_{\mathrm{ALK}}$ values in our study suggests major paleo-vegetation community change. As far as we focused on compound-specific $\delta^{13} \mathrm{C}_{\mathrm{ALK}}$ between $3.0 \mathrm{ka}$ and $1.0 \mathrm{ka}$, it is not complicated to compare each $n$-alkane compound provenance. However, $\delta^{13} n \mathrm{C}_{29}$ shows lighting trend from $3.0 \mathrm{ka}$ to $1.0 \mathrm{ka}$, indicating decrease of C4 plant. As indicated in Fig. 7, compound-specific $\delta^{13} \mathrm{C}_{\mathrm{ALK}}$ may show some switching points at about $1.0 \mathrm{ka}$ and $0.2 \mathrm{ka}$. This means that $n$-alkane compound changes would be matched well with its corresponding $\delta^{13} \mathrm{C}_{\mathrm{ALK}}$.

The excursions of $\delta^{13} n C_{29}$ and $\delta^{13} n C_{31}$ are quite different from those of $n C_{29}$ and $n C_{31}$ even though both concentrations of $n \mathrm{C}_{29}$ and $n \mathrm{C}_{31}$ show rather homogenous excursion between $3.0 \mathrm{ka}$ and $0.5 \mathrm{ka}$ in two core site (Fig. 8). The difference of compound-specific $n$-alkane source can be expressed $\operatorname{as} \square \delta^{13} \mathrm{C}_{\text {ALK }}$. Relatively large difference in $\delta^{13} \mathrm{C}_{\mathrm{ALK}}$ (around - 1.5) appeared between 3.0 ka and 2.0 ka may imply differences of vegetation community at this interval, and correspond to paleovegetation change from $\mathrm{C}_{4}$ 
plants to $C_{3}$ plants. As mentioned, this interval is regarded as wetter climatic interval, so depleted $\delta^{13} n C_{31}$ in SJP15-4 may support paleo-vegetation community changes. As mentioned paleovegetation index, Paq, also indicate $C_{3}$ plant expansion is observed between $2.5 \mathrm{ka}$ and $1.0 \mathrm{ka}$. Therefore, compound-specific $\square$ $\delta^{13} n C_{\text {ALK }}$ strongly indicative of variations of compound source and supports individual $n$-alkane excursion roughly.

\subsection{Implication for paleoclimate variations in East Asia}

In East Asian region, the most well-known studies on paleoclimate variation during the past glacialinterglacial periods were carried out using stalagmites, which showed evidence of strong coincident variation with climatic variation in high-latitude ice core studies and East Asian monsoon variation (Xiao et al. 1999; Wang et al. 2005; Li et al. 2015). In these studies, $n$-alkanes proxies were also widely used to track past paleoclimate variation during the Quaternary period (Li et al. 2013; 2015; Street et al. 2013; Hyun et al. 2017). Several previous records have focused on Holocene climate changes by using indirect proxies such as detrital quartz in Yangtze River off inner shelf area (Wang et al. 2020), and influx of quartz as an indicator of aeolian dust in Cheju Island, Korea (Lim et al. 2005; Lim and Matsumoto 2008). These studies used proxies associated with the East Asian monsoon system. Therefore, detecting any of these climatic events at a high-resolution scale is important for detailed assessments of paleoclimate variation in the East Asian monsoon area.

The concentration of $n$-alkanes, the $n \mathrm{C}_{31} / n \mathrm{C}_{27}$ proxy, and the $\delta^{13} \mathrm{C}_{\text {org }}$ values in this study show a distinguished variation since the mid-Holocene. Because these kinds of combined proxies imply humid conditions in East Asia (e.g., Li et al. 2013), our data showing a decreasing interval between $2.5 \mathrm{ka}$ and 0.5 ka may correspond to a wetter climatic condition as indicated by Li et al. (2013) in East Asian region. In this study, a climatic event-like 2.0 ka duration wetter condition during the late Holocene $(2.5-0.5 \mathrm{ka})$ is strongly coupled with decreasing fine quartz flux in Cheju Island (Lim et al. 2005). One of similar result can be found from the detrital quartz from the Yangtze River, off East China Sea (Wang et al. 2020) (Fig. 9B). This earlier study indicated that enhanced and/or reduced EASM intensity strongly associated with southward shift of EASM precipitation during this interval. General heavier trend of $\delta^{13} \mathrm{C}_{\text {org }}$ between 2.5 and $0.5 \mathrm{ka}$ in our core records (Fig. 9E) may support this EASM intensity.

As a paleoclimate monsoon variation, our $n$-alkane data clearly show gradational variation during $2.5 \mathrm{ka}$ to $0.5 \mathrm{ka}$. The total $n$-alkane concentration shows upward increasing from $2.5 \mathrm{ka}$, then peaked at $1.2 \mathrm{ka}$ in SJP15-2 and at $0.2 \mathrm{ka}$ in SJP15-4, and then start to decrease at $0.2 \mathrm{ka}$. Individual $n \mathrm{C}_{22}$ and $n \mathrm{C}_{24}$ records showed an abrupt increase between $2.5 \mathrm{ka}$ and $0.2 \mathrm{ka}$ in SJP15-4. These mid-chain $n$-alkanes that originate from floating plants indicate that floating macrophytes flourished at these periods.

Lim et al. $(2008 ; 2015)$ demonstrated that paleoclimatic changes in Korea may be associated with the East Asian monsoon and the D-O cycle based on the input of aeolian quartz records from the Cheju Island, South Korea. In these result, the paleovegetation of Cheju Island was strongly linked with East 
Asian monsoon climatic variation, and the quartz influx has been influenced by the pathway change of the westerlies. In our study, gradational changes between $2.5 \mathrm{ka}$ and $0.5 \mathrm{ka}$ may correspond to long range of global climatic variation, and might be associated with East Asian monsoon environmental changes since the mid-Holocene (Fig. 9C). The clear decrease of influx of aeolian quartz begin at about $2.3 \mathrm{ka}$, and it show gradational decrease until $0.5 \mathrm{ka}$. The timing of this fine quartz input is rather later than our $n$ alkane record. Nevertheless, assuming that decrease of fine quartz influx as diminished westerlies, and thus more moisture, in turn, this decrease influx of fine quartz may bring vegetation changes; the changes of total concentration of $n$-alkanes.

Large amounts of terrestrial leaf-wax $n$-alkanes would have been transported, particularly during glacial periods and the Holocene. Due to the dry conditions during glacial periods in East Asia, terrestrial $n$ alkanes were transported far across the Pacific Ocean (Ohkouch et al. 1997) and the East Sea (Yokoyama et al. 2006). Also, aeolian dust from mainland China could be transported via the westerlies to Cheju Island (Lim et al. 2005; Lee et al. 2014) and even in present study area. A large amount of terrestrial leaf wax could have been derived from nearby land areas. Therefore, our record of $n$-alkane concentrations and their carbon isotopes reflects information about not only the in situ paleo plant community but also allochthonous terrestrial $n$-alkanes which were associated with east Asian monsoon climatic variation. Allochthonous leaf wax could be transported from nearby and faraway places, and these delivery variations could have been associated with local climatic changes, as well as East Asian monsoon variation.

\section{Conclusions}

The time-dependent distributions of sedimentary $\delta^{13} \mathrm{C}_{\text {org }}(\% \circ)$ and $n$-alkanes of organic matter were investigated to link paleoclimate and oceanographic changes since the mid-Holocene. The proxies (TOC, $\delta^{13} \mathrm{C}_{\text {org }}, n$-alkanes, $\delta^{13} \mathrm{C}_{\mathrm{ALK}}$ ), representative terrestrial biomarkers, and long-chain $n$-alkanes exhibited gradational variations. In particular, $2.5 \mathrm{ka}, 0.5 \mathrm{ka}$ are switching points, indicating that the input of terrestrial biomarkers has been changed in accordance with paleoclimate variation in East Asia.

The proxies, including $A C L, C P I$, and $\mathrm{P}_{a q}$, also strongly coincide with the excursions of long-chain $n$ alkanes. In particular, $n \mathrm{C}_{31} / n \mathrm{C}_{27}$ describe a parabola during $3.5 \mathrm{ka}$ to $1.0 \mathrm{ka}$, implying gradual and wetter climatic conditions. Compound-specific $\delta^{13} \mathrm{C}_{\mathrm{ALK}}$ indicates more clearly distinguished switching boundaries, and show clear difference of compound source between $3.0 \mathrm{ka}$ and $1.0 \mathrm{ka}$. A synthetic comparison with previous works indicated that most paleoclimate proxies of stalagmites, fine quartz, and detrital quartz show coincident variation, and are well matched with our $n$-alkanes proxy. Therefore, this study provides information on paleoclimate variation that might have been regulated by centennial-scale dynamics such as the East Asian monsoon as well as local paleoclimate effects since the mid-Holocene in the southern inner continental shelf of the Korean peninsula. In this study, specially, distinctive wetter climate condition during Late-Holocene (2.0 ka $0.5 \mathrm{ka}$ ) has been prevailed in southern inner shelf of Korean peninsula. 


\section{Abbreviations}

KCC

Korean Coastal Current; TWC:Tsushima Warm Current; EASM:East Asian Summer Monsoon; EAWM:East Asian Winter Monsoon

\section{Declarations}

\section{Availability of data and material}

The dataset supporting the conclusions of this article is available in the Korea Institute of Ocean Science and Technology. Please contact author for data requests.

\section{Funding}

This work was supported by KIOST grant (PE99775) and K-IODP program (PM61460)

\section{Competing interests}

The authors declare that they have no competing interest.

\section{Authors' contributions}

SM (the first author) designed and proposed this study, and also made manuscript. JW carried out the experimental study and arranged the data. JH draw the figure and discussed the content. GY provide funding and review. All authors read and approved the final manuscript.

\section{Authors' information}

SM have been interested in paleoclimatology and paleoceanographic fields for more than twenty years, also he published several papers with similar methods of $n$-alkanes and its isotopic study. Recently he changed his interest into Holocene period because Holocene holds more important knowledge which is close to environmental state between nature and human beings. As a principal scientist in KOST, he like to contribution on the research of Holocene paleoenvironmental study through this kind of work. This is the second submission to PEPS, and willing to more contribute to this journal.

\section{Acknowledgements}

The authors thank anonymous reviewers for their critical reading of the original document. The first author thanks to Dr. Irino and Wang, Hokkaido University, and Dr. Lim, Korea Institute of Geoscience and Mineral Resources (KIGAM), for their valuable provide of raw data and comments and suggestions, in particular. This study was conducted with support from Korea Institute of Ocean Science and Technology (KIOST) grants (PE99775). The Korea International Ocean Discovery Program (K-IODP) program (PM61460) also supported this study. 


\section{References}

Ahad JME, Ganesharm RS, Bryant CL, Cisneros-Dozal LM, Ascough PA, Fallick AE, Slater GF (2011) Sources of n-alkanes in an urbanized estuary: Insights from molecular distributions and compoundspecific stable and radiocarbon isotopes. Mar Chem 126: 239-249.

Alves EQ, Macario K, Ascough P, Ramsey CB (2018) The worldwide marine radiocarbon reservoir effect: definitions, mechanisms, and prospects. Reviews of Geophysics. 10.1002/2017RG000588.

An Z, Porter SC, Kutzbach JE, Wu X, Wang S, Liu X, Li XQ, Zhou WJ (2000) Asynchronous Holocene optimum of the East Asian monsoon. Quat Sci Rev 19:743-762.

Badejo AO, Hyun S, Kim W, Ju SJ, Song B (2017) Sources and distribution of allochthonous organic matter in surface sediment from the Seomjin River to the southern inner Shelf of Korea. Ocean Sci J52(4):489-499.

Bush RT, Mclnerney FA (2013) Leaf wax $n$-alkane distributions in and across modern plants: Implications for paleoecology and chemotaxonomy. Geochim. Cosmochim. Acta 117: 161-179.

Chu G, Sun Q, Xie M, Lin Y, Shang W, Zhu Q, Shan Y, Xu D, Rioual P, Wang L, Liu J (2014) Holocene cyclic climatic variations and the role of the Pacific Ocean as recorded in varved sediments from northeastern China. Quat Int 102: 85-95.

Cloern JE, Canuel EA, Harris D (2002) Stable carbon and nitrogen isotope composition of acquatic and terrestrial plants of San Francisco Bay estuarine system. Liminol Oceanogr 47: 713-729.

Collister JW, Rieley G, Stern B, Eglinton G, Fry B, (1994) Compound-specific $\mathrm{d}^{13} \mathrm{C}$ analyses of leaf lipids from plant with differing carbon dioxide metabolisms. Org Geochem 21: 619-627.

Eglinton TL, Eglinton G (2008) Molecular proxies for paleoclimatology. Earth Planet Sci Lett 275: 1-16.

Farrington JW, Trip, BW (1977) Hydrocarbons in western North Atlantic surface sediments. Geochim. Cosmochim. Acta 41:1627-1641.

Ficken KJ, Street-Perrott FA, Perrott RA, Swain DL. Olago DO, Eglinton G (1998) Glacial/interglacial variations in carbon cycling revealed by molecular and isotope stratigraphy of Lake Nkunga, Mt. Kenya, East Africa. Org Geochem 29: 1701-1719.

Hedges JI, Prahl FG (1993) Early diagenesis: consequences for applications of molecular biomarkers. In: Engel, M.H., Macko, S.A. (Eds.) Organic Geochemistry: principles and applications. Plenum Press, New York, pp. 237-253.

Horikawa K, Murayama M, Minagawa M, Kato Y, Sagawa T (2010) Latitudinal and downcore (0-750 ka) changes in n-alkane chain lengths in the eastern equatorial Pacific. Quat Res 73:573-582. 
Hu L, Guo Z, Feng J, Yang Z, Fang M (2009) Distributions and Sources of bulk organic matter and aliphatic hydrocarbons in surface sediments of the Bohai Sea, China. Mar Chem 113: 197-211.

Hu J, Peng P, Jia G, Mai B, Zhang G (2006) Distribution and sources of organic carbon, nitrogen and their isotopes in sediments of the subtropical Pearl River estuary and adjacent shelf, Southern China. Mar Chemi 98: 274-285.

Hyun S, Lee T, Jung SK (2011) Contents and stable isotope composition of organic carbon and total nitrogen in the surface sediment of two coastal bays in Korea. Ocean Sci J 46: 289-297.

Hyun S, Lim DI, Yoo HS (2006) Transgressive geochemical records in the East China Sea: a perspective with Holocene Paleoceanography. Econ Environ Geol 39:53-61.

Ikehara K (2000). Comparison of radiocarbon ages of planktonic foraminifera and bulk organic carbon in marine sediments. Bull. Geol. Surv. Japan 51(7):299-307.

Jeng WL (2006) Higher plant $n$-alkane average chain length as an indicator of petrogenic hydrocarbon contamination in marine sediments. Mar Chem 102: 242-251.

Jia G, Bai Y, Yang X, Xie L, Wei G, Ouyang T, Chu G, Liu Z, Peng P (2015) Biochemical evidence of Holocene East Asian summer and winter monsoon variability from a tropical maar lake in southern China. Quat Sci Rev 111, 51-61.

Kang HS, Won EJ, Shin KH, Yoon HI (2007) Organic carbon and nitrogen composition in the sediment of Kara Sea, Arctic Ocean during the Last Glacial Maximum to Holocene times. Geophys Res Lett 34:

L12607.

Kim DC, Kang HJ (1991) Suspended sediment budget in Gwangyang bay through the Yeosu sound. Korea J Fish Aquat Sci 24:31-38.

KMC (1890) Report on the Seomjin River investigation. Korea Ministry of Construction (KMC), Seoul 203 pp (in Korean).

Lee MK, Lee SH, Lee YI, Yoo HI, Yoo KC (2014) Rare earth element composition of pale-maar sediments (latest Pleistocene-Early Holocene), Jeju Island, Korea: implications for Asian dust record and monsoon climate. Qaut Int 433: 32-42.

Li L, Li Q, Li J, Wang H, Dong L, Huang Y, Wang P (2015) A hydroclimate regime shift around 270 ka in the western tropical Pacific inferred from a late Quaternary n-alkane chain-length record. Paleogeo Paleoclimat Paleoecol 427: 79-88.

Li L, Li Q, Tian J, Wang H, Wang P (2013) Low latitude hydro-climatic changes during the PlioPleistocene: evidence from high resolution alkane records in the southern South China Sea. Quat Sci Rev 78: 209-224. 
Lim J, Matsumoto E, Kitagawa H (2005) Eolian quartz flux varitions in Cheju Island, Korea, during the last $6500 \mathrm{yr}$ and a possible Sun-monsoon linkage. Qua Res 64:12-20.

Lim J, Matsumoto E (2008) Fine Aeolian quartz records in Cheju Island, Korea, during the last 6500 years and pathway change of the westerlies over east Asia. J Geophys Res 113, D08106, doi:10.1029/2007JD008501.

Lim J, Yang DY, Lee JY, Hong SS, Um IK (2015). Middle Holocene environmental change in central Korea and its linkage to summer and winter monsoon changes. Qua Res 84: 37-45.

McKirdy DV, Thorpe CS, Haynes DE, Grice K, Krull ES, Halverson GP, Webster LJ (2010) The biogeochemical evolution of the Coorong during the mid- to late Holocene: An elemental, isotopic and biomarker perspective. Org Geochem 41: 96-110.

Middelburg JJ, Nieuwenhuize $\mathrm{J}$ (1998) Carbon and nitrogen stable isotopes in suspended matter and sediments from Schelde Estuary. Mar Chem 60: 217-225.

Minoura K, Hoshino K, Nakamura T, Wada E (1997) Late Pleistocene-Holocene palroproductiity circulation in the Japan Sea: sea-level control on $\delta^{13} \mathrm{C}$ and $\delta^{15} \mathrm{~N}$ records of sediment organic material. Paleogeo Paleoclimatol Paleoecol 135: 41-50.

Nagashima K, Tada R, Toyoda S (2013) Westerly jet-East Asian summer monsoon connection during the Holocene. Geochem Geophy Geosyst 14: 5041-5053. https://doi.org/10.1002/2013GC004931.

Naidu AS, Copper LW, Finney BP, Macdonald RW, Alexander C, Semiletov IP (2000) Organic carbon isotope ratios $\left(\delta^{13} \mathrm{C}\right)$ of Artic Amerasian Continental shelf sediments. Int. J. Earth Sci 89: 522-532.

Ohkouch N, Kawamura K, Kawahata H, Taira A (1997). Latitudinal distributions of terrestrial biomarkers in the sediments from the Central Pacific. Geochim Cosmochim Acta 61: 1191-1981.

Pancost RD, Boot CS, (2004) The paleoclimatic utility of terrestrial biomarkers in marine sediments. Mar Chem 92: 239-261.

Park SC, Yoo DG, Lee CW, Lee El (2000) Last glacial sea-level changes and paleogeography of the Korea (Tsushima) Strait. Geo-Mar Lett 20: 64-71.

Poynter JG, Eglinton G (1990) Molecular composition of three sediments from hole 717C: The Bengal fan. In J.R. Cochran, D.A.V. Stow et al. (Eds.), Proceedings of the Ocean Drilling Program Scientific Results. vol. 116 (pp. 155-161).

Seki O, Yoshikawa C, Nakatsuka T, Kawamura K, Wakatsuchi M (2006). Fluxes, source and transport of organic matter in the western Sea of Okhotsk: stable carbon isotope retios of n-alkanes and total organic carbon. Deep-Sea Res.1 153: 253-270. 
Sikes EL, Uhle ME, Nodder SD, Howard ME (2009) Source of organic matter in a coastal marine environment: Evidence from n-alkanes and their $\mathrm{d}^{13} \mathrm{C}$ distributions in the Hauraki Gulf, New Zealand. Mar. Chem. 113: 149-163.

Stein R, (1990) Organic carbon/sedimentation rate relationship and its paleoenvironmental significance for marine sediments. Geo-Mar Lett 10: 37-44.

Street JH, Anderson RS, Rosenbauer RJ, Paytan A (2013) n-Alkane evidence for the oneset of wetter conditions in the Sierra Nevada, California (USA) at the mid-late Holocene transition, 3.0 ka. Qua Res 79: $14-23$.

Tada R, Zheng H, Clift PD (2016) Evolution and variability of the Asian monsoon and its potential linkage with uplift of the Himalaya and Tibetan Plateau. Prog. Earth Planet Sci 3:4, http://doi.org/10.1186/s40645-016-0080-y.

Usui T, Nagao S, Yamamoto M, Suzuki K, Kudo I, Montani S, Noda A, Minagawa M (2006) Distribution and source of organic matter in surficial sediments on the self and slope off Tokachi, western North Pacific, inferred from $\mathrm{C}$ and $\mathrm{N}$ stable isotopes and $\mathrm{C} / \mathrm{N}$ ratios. Mar Chem 98: 241-259.

Visco AC, Pesando D, Bernard P, Marty JC (1993) Lipid components of the Mediterranean seagrass Posidonia Oceanica. Phytochem 34: 3381-3387.

Wang K, Tada R, Zheng H, Irono T, Zhou B, Saito K (2020) Provence changes in fine detrital quartz in the inner shelf sediments of the East China Sea associated with shifts in the East Asian summer monsoon front during the last 6 Kyrs. Prog Earth and Planeta Sci https://dog.org/10.1186/s40645-019-0319-5.

Wang K, Zheng H, Tada R, Irino T, Zheng Y, Saito K, Karasuda A (2014) Millennial-scale East Asia Summer monsoon variability recorded in grain size and provenance of mud belt on the inner shelf of the East China Sea during mid-to late Holocene. Quar Int 349: 79-89.

Wang YJ, Cheng H, Edward RL, He YQ, Kong XG, An ZS, Wu JY, Kelly MJ, Dykoski CA, Li XD (2005). The Holocene Asian monsoon: links to solar changes and North Atlantic climate. Science 308: 854-857.

Xiao JL, An ZS, Liu TS, Inouchi Y, Kumai H, Yoshikawa S, Kondo Y (1999) East Asian monsoon variation during the last 130,000 years: evidence from the loess plateau of central China and lake Biwa of Japan. Qua Sci Rev 18:147-157.

Yamamoto S, Kawamura K, Seki O, Meyers PA, Zheng Y, Zhou W (2010) Environmental influences over the last $16 \mathrm{ka}$ on compound-specific $\mathrm{d}^{13} \mathrm{C}$ variations of leaf wax $n$-alkanes in the Hani peat deposit from northeast China. Chem Geol 277: 261-268.

Yokoyama Y, Naruse T, Ogawa NO, Tada R, Kitazato H, Ohkouchi N (2006) Dust influx reconstruction during the last 26,000 years inferred from a sedimentary leaf wax record from the Japan Sea. Glo Planet 
Yoo DG, Kim SP, Chang TS, Kong GS, Kang NK, Kwon YK, Nam SL, Park SC (2014). Later Quaternary inner shelf deposits in response to late Pleistocene-Holocene sea level changes: Nakdong River, SE Korea. Qua Int 344: 156-169.

Zhang Z, Zhao M, Eglinton G, Lu H, Huang CY (2006) Leaf wax lipids as paleovegetational and paleoenvironmental proxies for the Chinese Loess Plateau over the last 170 kyr. Quat Sci Rev 25: 575594.

Zhou K, Xu H, Lam J, Yan D, Sheng E, Yu K, Song Y, Zhang J, Fu P, Xu S (2020). Variable Late Holocene ${ }^{14} \mathrm{C}$ reservoir ages in Lake Bosten, Northwerstern China. Frontier in Earth Science 7:1-11. doi: 10.3389/feat.2019.00328.

\section{Table}

Due to technical limitations, table 1 is only available as a download in the Supplemental Files section.

\section{Figures}
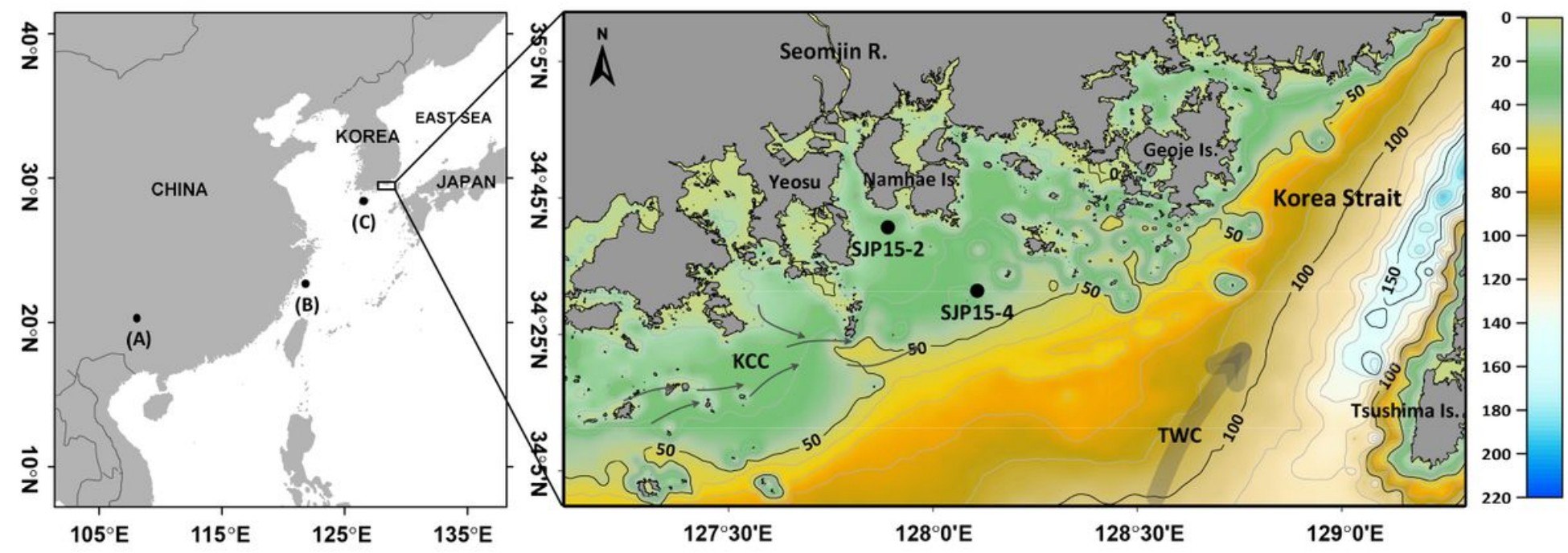

\section{Figure 1}

Sampling locations of the two core sediments collected from coastal area of southern continental shelf of Korean peninsula. Previous works cited in this study were indicated as black dots (left). (A) is Dongge cave (Dykoski et al. 2005), (B) off Yangtze River (Wang et al. 2020), and (C) is Cheju Island, Korea (Lim et al. 2005). KCC is Korean Coastal Current, TWC is Tsushima Warm Current, respectively. 
Fig. $2(14 \mathrm{C}$ age $)$
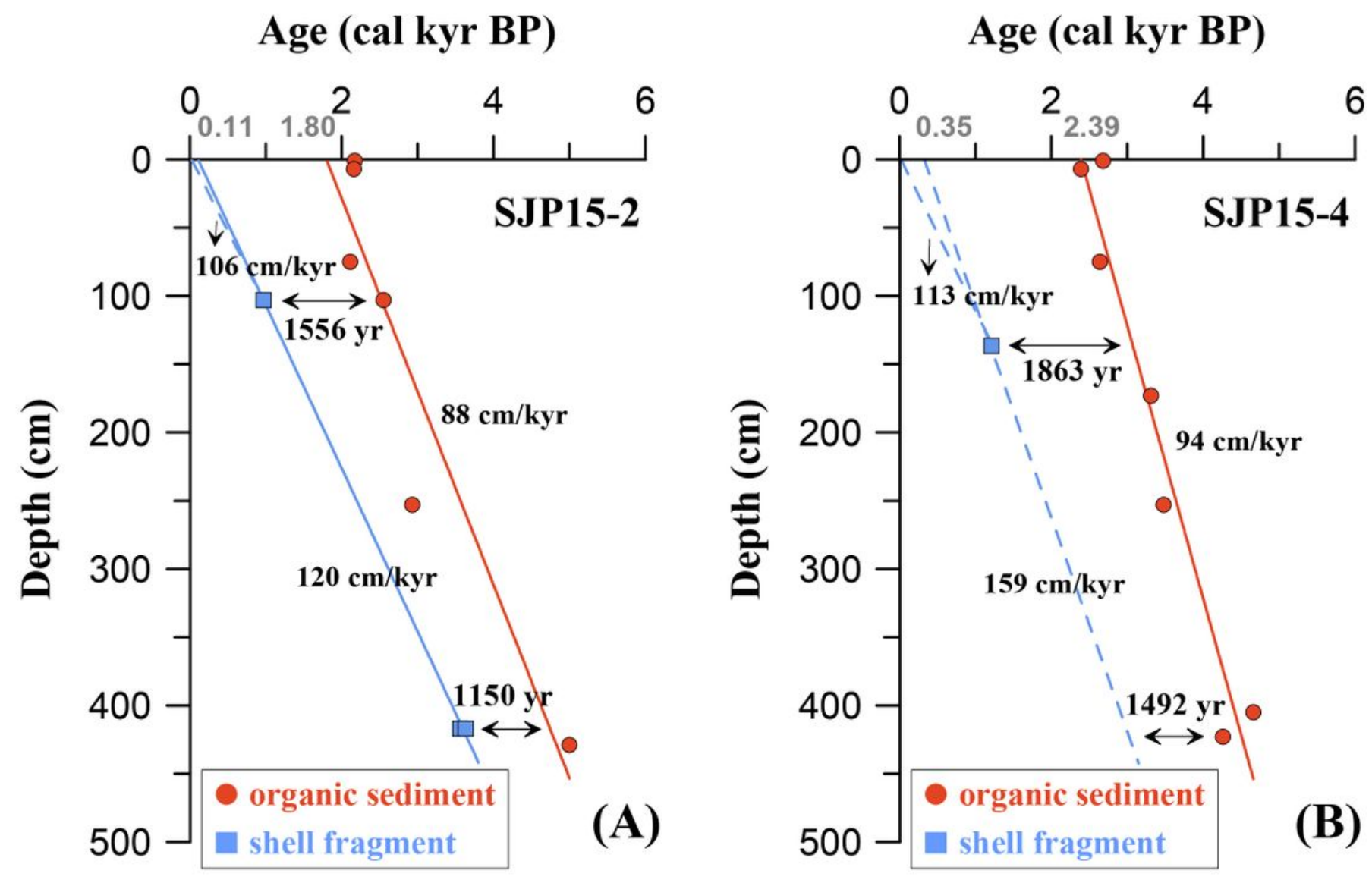

Figure 2

Sedimentation rate of the two cores. Both core show homogenous mud sediment and have a similar sedimentological characteristics and high sedimentation rate. A hypothetical line (broken line) in (B) was dawn by the age gab between bulk organic carbon and shell fragments (see text). 
Fig. 3 (3-point average)

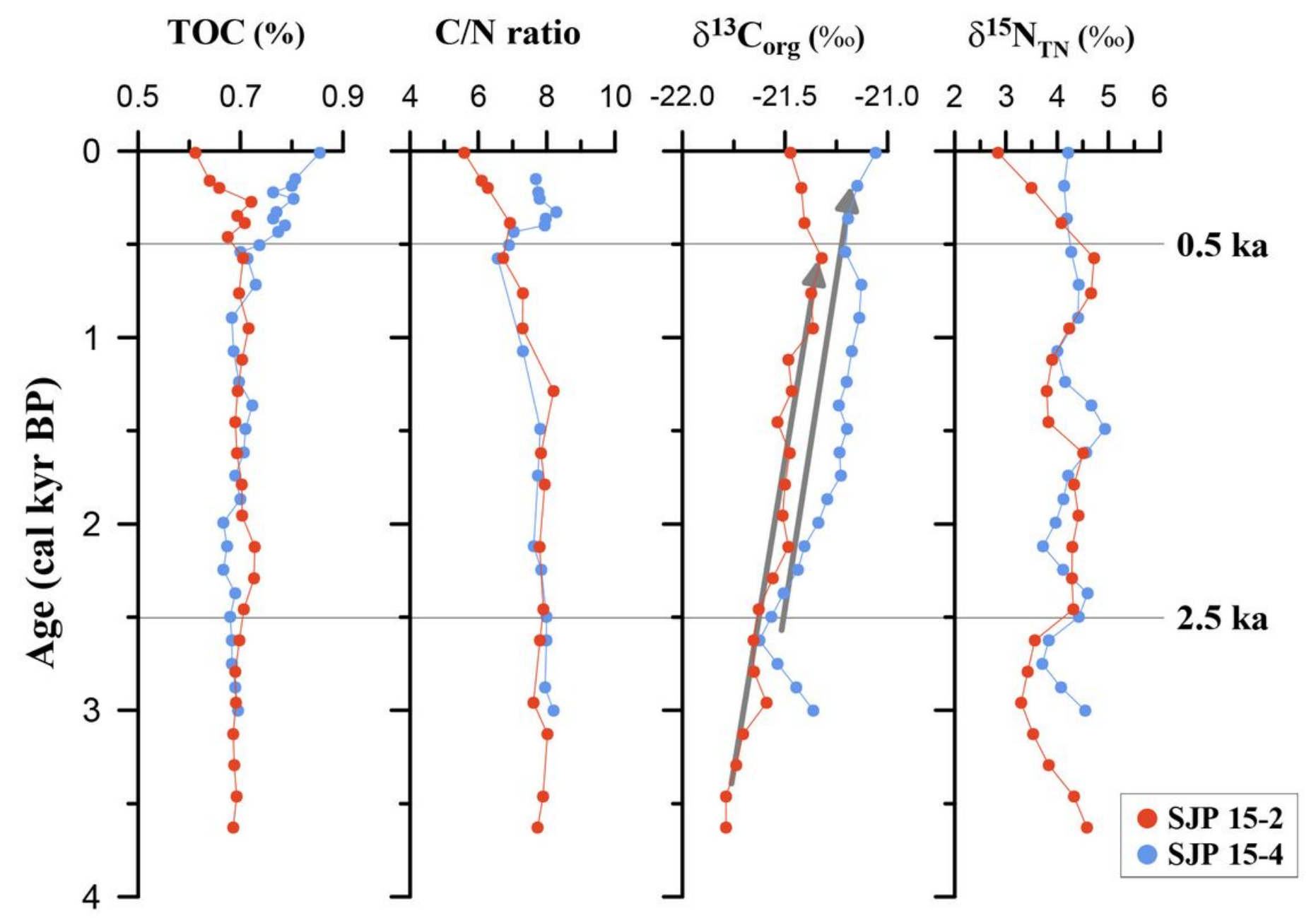

Figure 3

Vertical distributions of TOC (\%), C/N ratio, 813Corg (\%o) and 815NTN (\%o) in two cores. Data were drawn by three-point moving average. Distinctive two switching points $(2.5$, and $0.5 \mathrm{ka})$ in their excursion are shown by thin lines. 
Fig. 4 (3-point average)

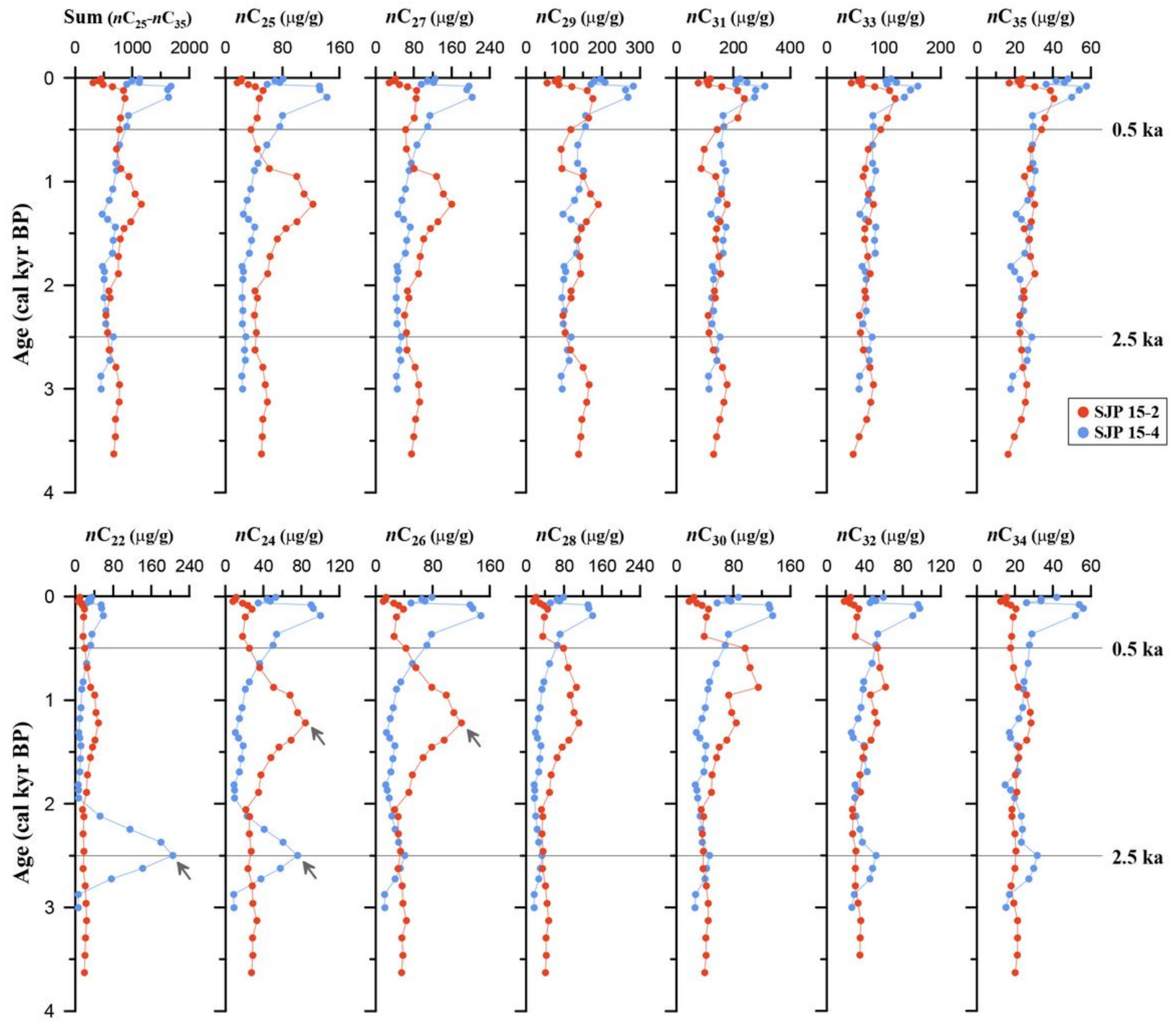

Figure 4

Vertical n-alkane distribution in two cores. The total concentration of n-alkanes (nC25-35) is calculated by sum from each nC25-nC35. Due to rather specific excursion in even-numbered n-alkanes distribution, odd and even number $\mathrm{n}$-alkanes profiles are illustrated together. 
Fig. 5
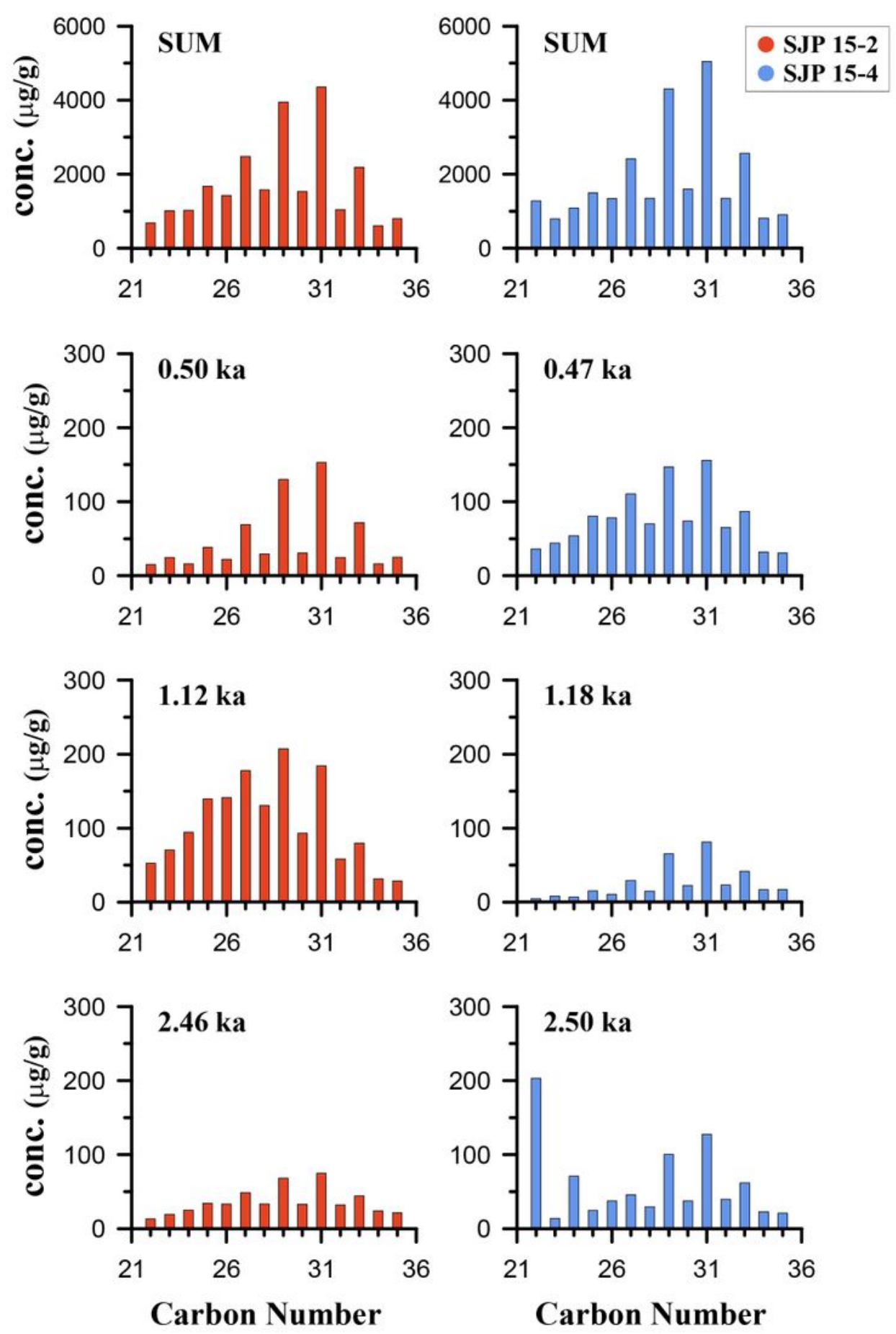

Figure 5

Representative individual n-alkane concentrations in studied two core. These time-dependent differences in concentration were attributed to changes in paleo-plant population and to supply changes of nalkanes. 
Fig. 6 (3-point average)

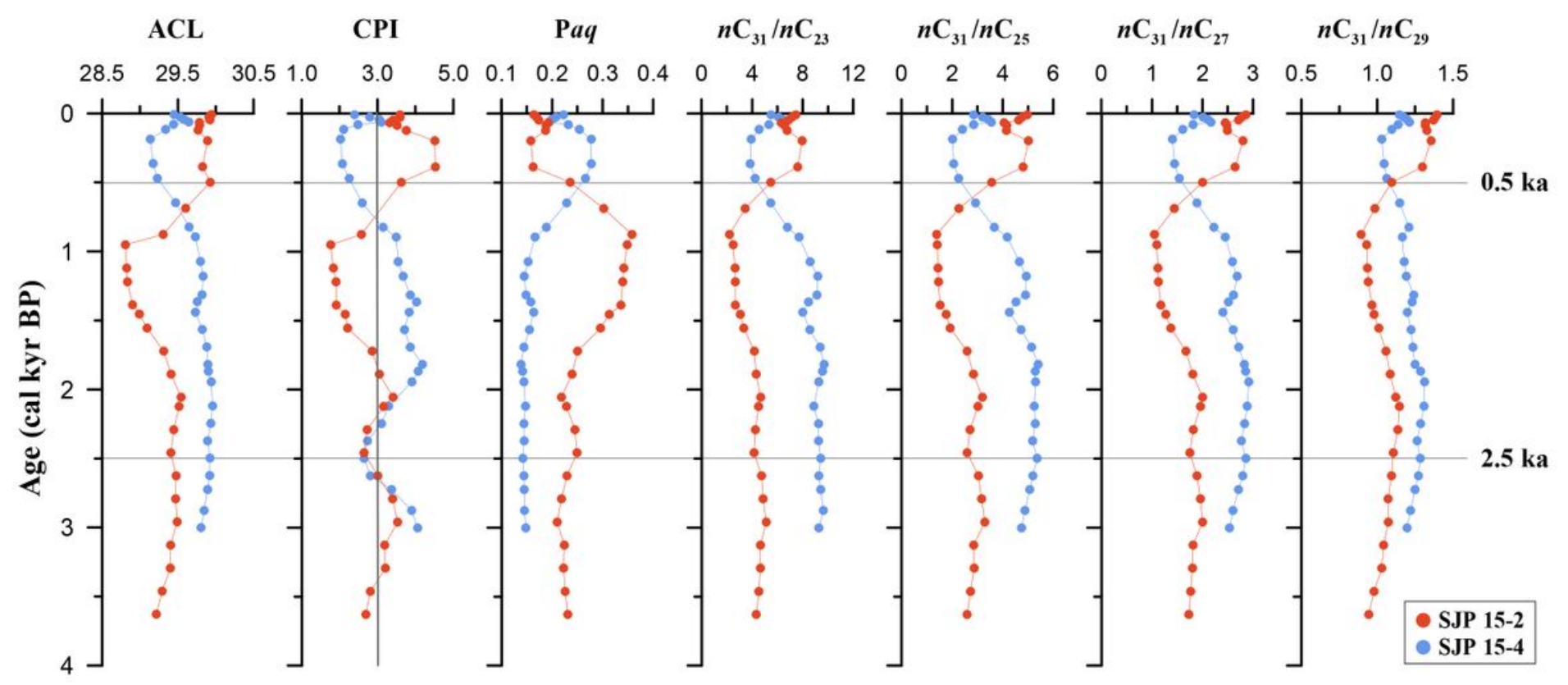

Figure 6

Average chain length $(\mathrm{ACL})$, carbon preference index $(\mathrm{CPI})$ and paleo-vegetation index (Paq). Several representative combined $n$-alkanes indices were also illustrated. These distinctive changes in proxies were very clear between $2.5 \mathrm{ka}$ and $0.5 \mathrm{ka}$, suggesting wetter climate condition and increase of C3 plant during this time.

Fig. 7 (3-point average)

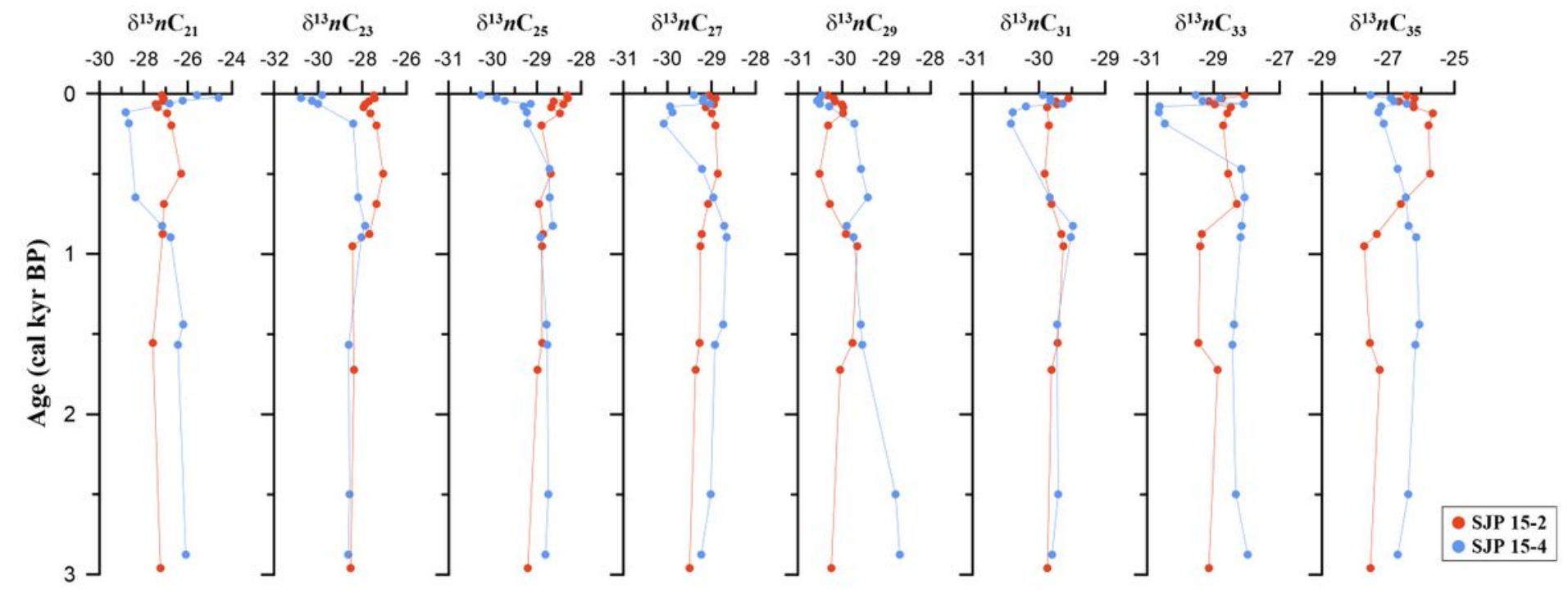

Figure 7 
Vertical profiles of odd-numbered compound-specific carbon isotope. The excursions are quite different in $\delta 13 n C 21, \delta 13 n C 23, \delta 13 n C 27, \delta 13 n C 33, \delta 13 n C 35$ suggesting provenance changes due to the paleovegetation change or/and supply change due to climatic changes.

Fig. 8 (3-point average)

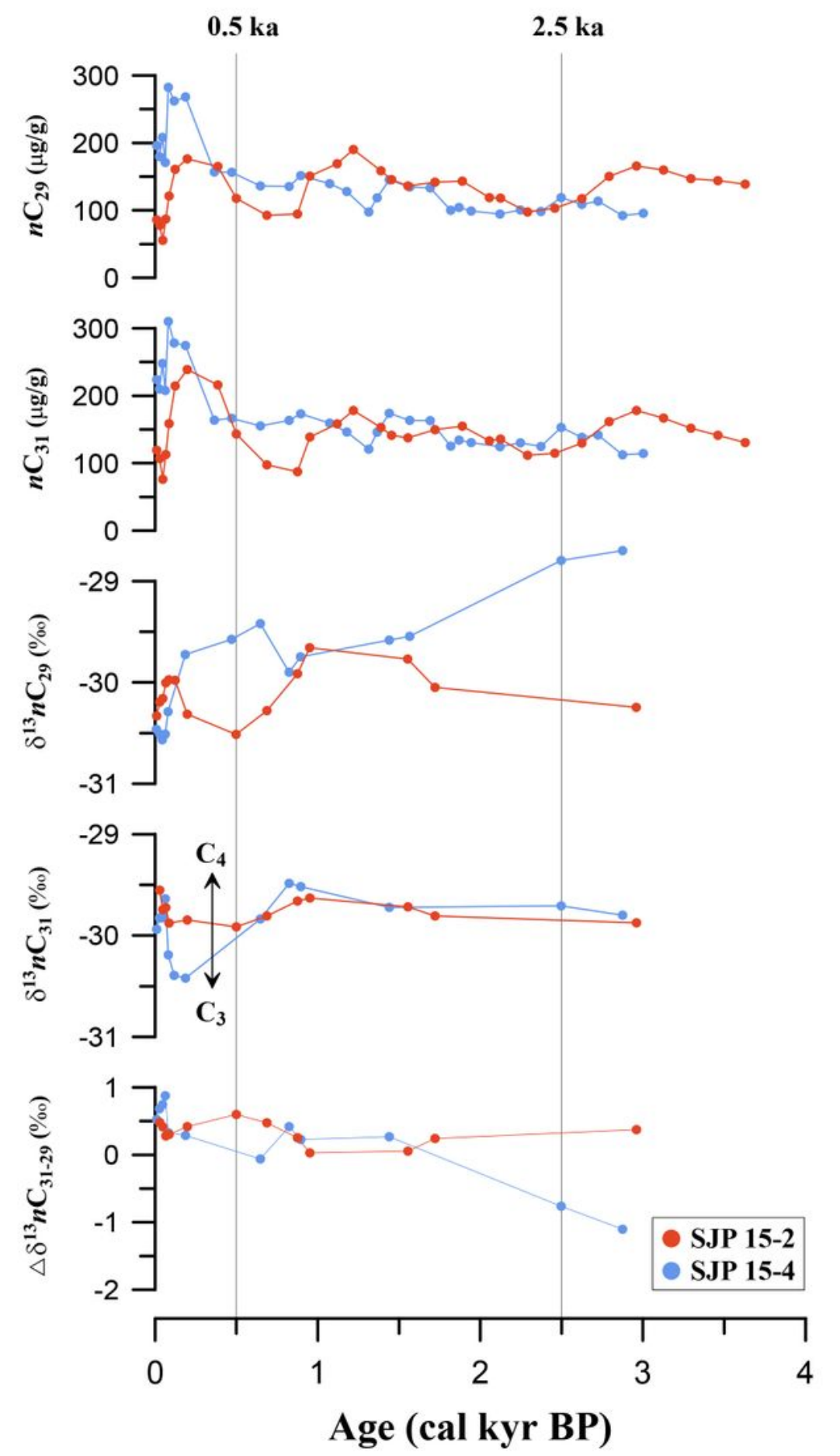

Figure 8

Comparison of single n-alkane compounds (nC29, nC31) and their compound-specific carbon isotope. The difference of compound-specific n-alkanes between two $\delta 13 n C 31, \delta 13 n C 29$ is show as * $\delta 13 n C 31$ - 
Fig. 9

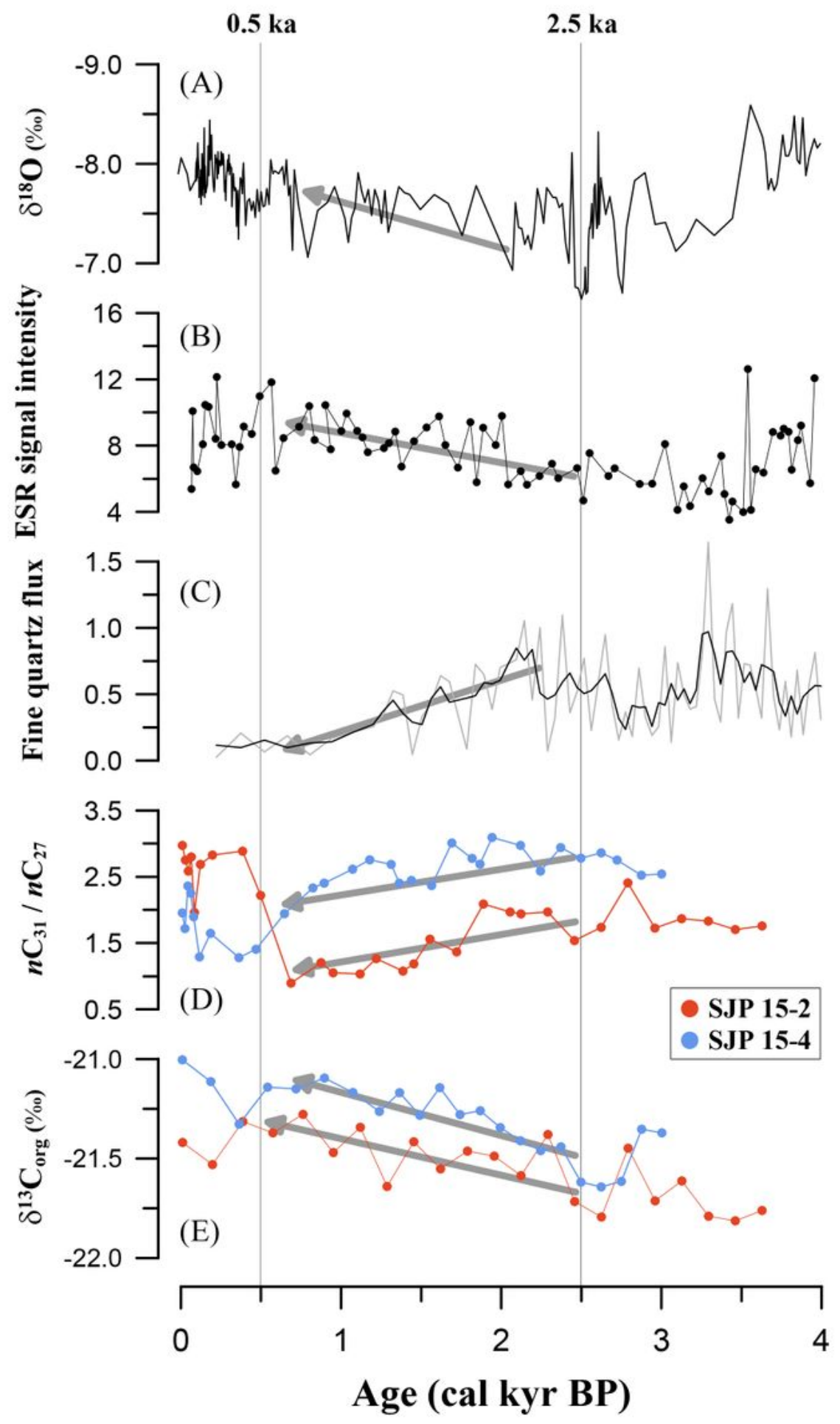

Figure 9

Synthetic comparison with previous works. (A) Dongge cave (Dykoski et al. 2005), (B) Yangtze River inner shelf (Wang et al. 2020), (C) Cheju Island, Korea (Lim et al. 2008), (D) nC31/nC27 (This study), (E) 813Corg (\%o) (This study). 


\section{Supplementary Files}

This is a list of supplementary files associated with this preprint. Click to download.

- SJP15Table1.pdf 